\title{
Microfilaria in Association with Adrenal Lymphoma Diagnosed on Cytology: An Extremely Rare Case Report
}

\author{
Sitoloji ile Tanı Konan Adrenal Lenfomayla İlişkili Mikrofilaria: \\ Çok Ender Görülen Bir Olgu Sunumu
}

\author{
Sushila JAISWAL, Gyan CHAND, Hira LAL, Mukul VIJ, Rakesh PANDEY
}

Department of Pathology, Sanjay Gandhi Postgraduate Institute of Medical Sciences, Lucknow, INDIA

\begin{abstract}
Filariasis is a common public health problem in Asian countries. In this report, the authors have described detection of microfilaria in the cytological specimen of adrenal lymphoma. To the best of our knowledge, this is the first reported case in the literature where microfilaria was seen in an adrenal gland involved by lymphoma. The literature is briefly reviewed.
\end{abstract}

Key Words: Microfilaria, Adrenal, Lymphoma, Fine-needle biopsy

\section{öz}

Filariasis Asya ülkelerinde sık görülen bir halk sağlığı problemidir. Bu raporda yazarlar adrenal lenfoma sitolojik örneği içinde mikrofilaria saptanmasını tanımlamaktadır. Bildiğimiz kadarıyla bu vaka sunumu literatürde adrenal bezde lenfoma tutulumu ile birlikte görülen ilk mikrofilaria vakasıdır. Literatür kısaca gözden geçirilmektedir.

Anahtar Sözcükler: Mikrofilaria, Adrenal, Lenfoma, İnce iğne biyopsisi

\section{INTRODUCTION}

Filariasis is a common health problem in tropical countries like India (1). In India, it is caused mainly by Wuchereria bancrofti and Brugia malayi $(2,3)$. Culex mosquito is the most important (>50\%) vector of Wuchereria bancrofti (4). The literature has few reports of incidental detection of microfilaria in many of the commonly evaluated cytological specimens such as thyroid, breast, pancreas and in body fluids associated with neoplastic lesions $(6,7,8)$. However, to the best of our knowledge, microfilaria associated with lymphoma of the adrenal gland has never been reported. The present report is the first case in the literature where microfilaria was seen in the adrenal gland involved by lymphoma.

\section{CASE REPORT}

A 55-year-old diabetic male presented with complains of fever, generalized weakness, weight loss and pain in the abdomen for the last 2 months. On physical examination there was blackish pigmentation over the face, palm, knuckles, feet and oral mucosa. There was no cervical, axillary and inguinal lymphadenopathy, hepatomegaly or splenomegaly. However, ultrasonography (USG) revealed

(Turk Patoloji Derg 2013, 29:143-145)

Received : 18.08.2011 Accepted : 23.11.2011 enlargement of adrenal glands as well as retroperitoneal lymph nodes. The patient underwent USG-guided fine needle aspiration (FNA) of an adrenal gland and retroperitoneal lymph nodes.

Smears prepared from USG-guided FNA using a 21 gauge needle from both retroperitoneal lymph nodes and adrenal gland were stained with air dried May-Grunwald Geimsa and ethanol-fixed Papanacolaou stains.

Smears from retroperitoneal lymph node and adrenal glands were suggestive of lymphoma. The FNA smears from the left adrenal were paucicellular and showed the presence of few scattered atypical lymphoid cells in the hemorrhagic background along with a few microfilariae. These microfilaria showed nuclei in the centre and a tip free of nuclei, and there was a sheath projecting beyond the body of the larvae (Figure 1). Laboratory investigation revealed a hemoglobin of 9.4 gram \%, total leukocyte count of $9,700 / \mathrm{mm}^{3}$ and platelet count was 250000 per $\mathrm{cmm}$. Peripheral blood smear examination showed a differential of polymorphs $70 \%$ and lymphocytes $30 \%$. There was no eosinophilia, parasites or atypical cells. Bone marrow aspiration and biopsy did not show any evidence of lymphomatous infiltration and were within normal limits.

Correspondence: Sushila JAISWAL

Sanjay Gandhi Postgraduate Institute of Medical Sciences,

Rae Bareli Road, Lucknow 226014 UP, INDIA

E-mail: sushilapath@yahoo.com Phone: +91522 2495240 


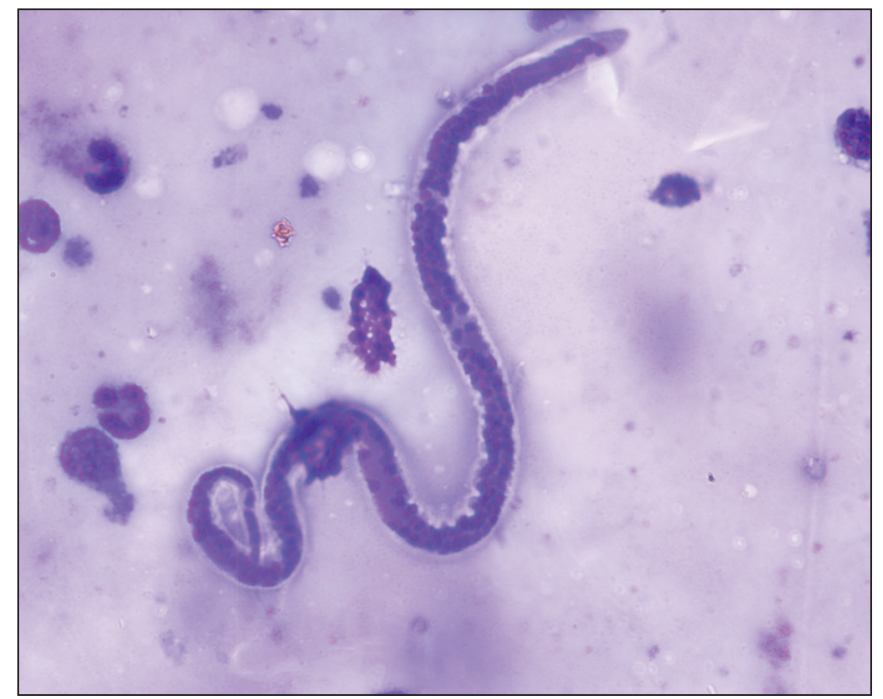

Figure 1: MGG-stained smear showing presence of microfilaria in a background of dispersed population of atypical lymphoid cells.

Histopathological and immunohistochemical confirmation of Non-Hodgkin's B cell lymphoma was done as advised on cytology. Although no microfilaria was seen in the paraffinembedded sections, the sections from both the lymph node and adrenal biopsy showed tumor composed of sheets of atypical lymphoid cells displaying round to oval nuclei, dispersed chromatin, inconspicuous nucleoli and scant cytoplasm (Figure 2). Mitotic activity was occasional. On immunohistochemistry, the tumor cells were positive for Leucocyte common antigen (CD45) (Figure 3) and CD20 and were negative for pancytokeratin and CD3.

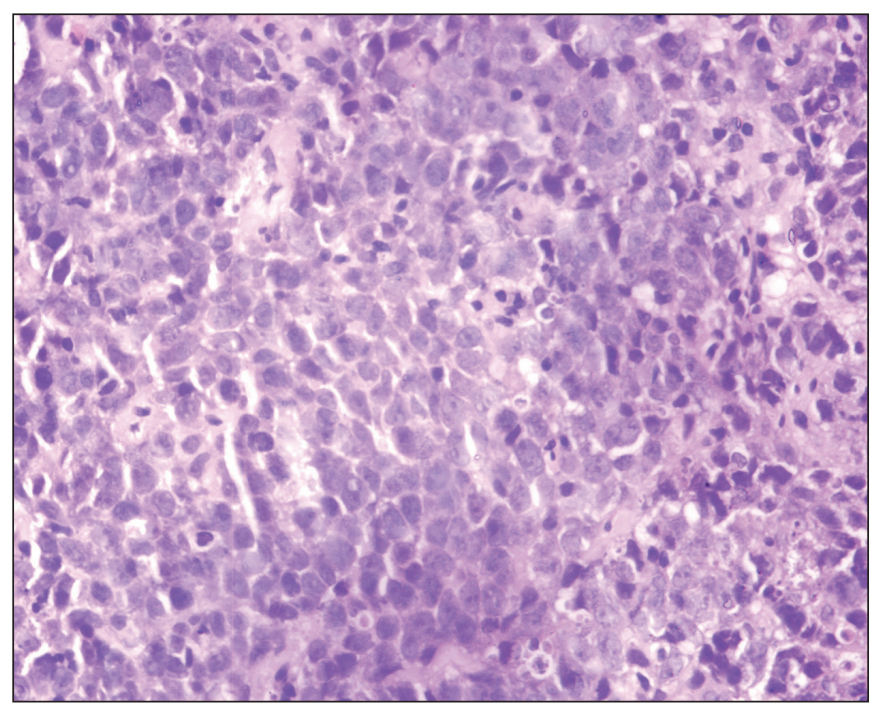

Figure 2: H\&E-stained sections of the adrenal biopsy showing tumor disposed in sheets displaying medium-sized atypical lymphoid cells.

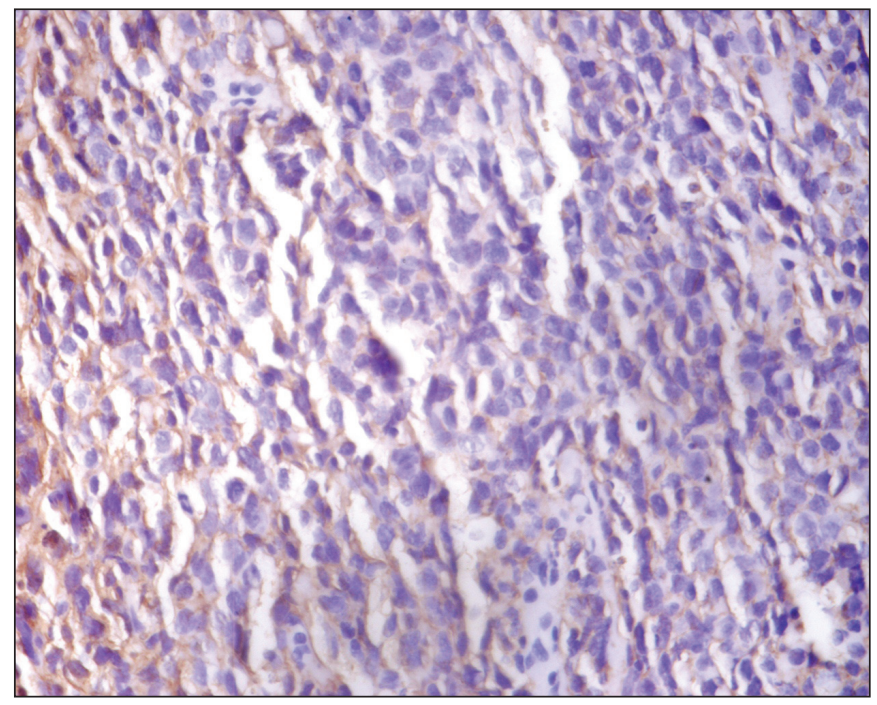

Figure 3: Immunohistochemistry shows leucocyte common antigen positivity by tumor cells.

\section{DISCUSSION}

Microfilaria is a nematode belonging to the superfamily Filarioidea and is found in the blood and skin. Lymphatic filariasis is a major health problem in tropical and subtropical countries in Asia and the Pacific Island (1). It is estimated that about 600 million people live in areas endemic for lymphatic filariasis in Southest Asia (2). Eight filarial species infect the human but serious infestation is caused by only four, i.e. Wuchereria bancrofti, Brugia malayi, Onchocerca volvolus and Loa loa $(1,3)$.

Wuchereria bancrofti is the most common causative organism, accounting for about $95 \%$ of all filarial infections. It was first reported in 1876 by Bancroft in Brisbane and the term filarial bancrofti was given in 1977. The life cycle is completed in two hosts. Man is the definitive host and the female Culex quinquefasciatus, the most important $(>50 \%)$ vector of Wuchereria bancrofti, acts as an intermediate host (4).

When a Culex mosquito bites an infected individual, the sheathed microfilarias are ingested by the mosquito. These microfilarias transform into first, second and third staged larvae. These infected third-stage larva are inoculated in uninfected humans by a mosquito bite and develop into the adult worm in the lymphatic system. This prepatent period of growth of third-stage larvae to adult worm lasts for about one to one and half years and is seldom symptomatic. The chronic stage may develop in some patients, while others may remain asymptomatic for many years (5). The chronic stage usually develops 10 to 15 years later, in persons exposed continuously to reinfection. The most commonly 
involved lymphatics are those of lower limb, retroperitoneal tissue, spermatic cord, epididymus and mammary gland. The diagnosis of microfilaria is conventionally made by demonstration of microfilaria in the peripheral blood smear. It causes a spectrum of disease including lymphangitis, lymphadenitis, hydrocele, chyluria and elephantiasis. In occult filariasis, adult microfilarias are not present in the blood but are seen in the affected tissue. The diagnosis in asymptomatic and occult filariasis is therefore difficult by blood examination.

A review of the literature reveals incidental detection of microfilaria in many of the commonly performed cytological specimens and has been described in almost all tissues of the body. Thyroid, breast, pancreas and body fluids associated with neoplastic lesions are a few examples $(6,7,8,9)$. The adrenal gland is another rare site that is also involved by lymphoma. To the best of our knowledge, this is the first case reported in the literature where microfilarias were seen in adrenal gland involved by lymphoma. Their presence in association with tumors involving lymph nodes and lymphatics can be explained by their being normal habitation for the filarial organism. However, this view does not completely explain their association with tumors from other sites. As the retroperitoneal lymph node also revealed lymphomatous infiltration in this case, the possible explanation is that it might have infiltrated from its normal habitant lymph node via the vascular supply to the adrenal gland along with the atypical lymphoid cells. Increased concentration at the tumor site and subsequent rupture and hemorrhage causes release of parasite into the tumor tissue. However, the retroperitoneal lymph node showed no evidence of microfilaria on cytology as well as on biopsy.

In conclusion; Fine needle aspiration cytology (FNAC) is not the method of choice for diagnosis of microfilaria unlike the peripheral blood smear examination. However, cases have been detected as a co-incidental finding on cytology like the index case where the patient was subjected for FNAC to diagnose or confirm some other lesion. The illustrated case is the first case reported in the literature to the best of our knowledge where microfilaria is associated with adrenal lymphoma and highlights the value of proper and careful screening of the cytological smears in the detection of asymptomatic and clinically unsuspected cases of Bancrofti filariasis even if smears are hypocelluar, hemorrhagic or display atypical cells. Timely institution of the specific therapy obviates the severe manifestation of lymphatic obstruction.

\section{REFERENCES}

1. Nutman TB, Weller PF: Filarial and Related Infections. In: Harrison's Principles of Internal Medicine, 16th edn. Kasper DL. Brunwald E, Fauci AS, Hauser SL, Longo DL, Jameson JL, (Eds): New York, Mc Grew Hill, 2005, 1260-1266

2. Park K: Epidemiology of Communicable Diseases. In Park JE, Park K, (Eds): Textbook of Preventive and Social Medicine, 20th ed., Jabalpur, Banarasidas Bhanot, 2005,199-204

3. Gupta S, Sodhani P, Jain S, Kumar N: Microfilaria in association with neoplastic lesions. Report of five cases. Cytopathology 2001, $12: 120-126$

4. Arora DR, Arora B: Medical Parasitology. 2nd ed., Delhi, SDR, 2005, 184-190

5. Gutierrez Y. Spiruida: Filariae of the lymphatics. In: Diagnostic Pathology of Parasitic Infections with Clinical Correlation. 2nd ed. 2000, 433-444

6. Agarwal PK, Srivastava AN, Agarwal N: Microfilaria in association with neoplasms. A report of six cases. Acta Cytol 1982, 26:488-490

7. Justus PG, Kitchens CS: Secondary leukemia with Munchausen filariasis. Ann Intern Med 1976, 85:685

8. Dey P, Radhika S, Jain A: Microfilaria of Wuchereria bancrofti in lymph node aspirate: A case report. Acta Cytol 1993, 37:745-746

9. Gupta S, Jain S, Sodhani P: Breast carcinoma with co-existent microfilariasis and filarial lymphadenitis diagnosed on cytology. Breast J 2011;17:100-102 